\section{Muscle and silk}

Conformation in Fibrous Proteins and Related Synthetic Polypeptides. By R. D. B. Fraser and T. P. MacRae. Pp. xviii+628. (Molecular Biology: An International Series of Monographs and Textbooks.) (Academic: New York and London, December 1973.) \$45; £19.50.

THE fibrous proteins form an important class among the complex structures found in living organisms, and the investigation of their structure poses special problems because they cannot, in general, be obtained in the form of single crystals suitable for $\mathrm{X}$-ray investigation. The first part of this book describes the major techniques in current use and their application to the problems. They include $\mathrm{X}$-ray, electron and optical diffraction, electron microscopy, infrared spectroscopy (using polarised radiation) and the important if less direct techniques based on the use of known atomic dimensions and interaction energies which may be described as model building. There is also a chapter on methods for obtaining the optimum structure and another on several techniques of more limited application.

The second part describes in considerable detail the several well-characterised conformations found in synthetic polypeptides ( $\alpha$-helix, $\beta$-conformation and so on) which have been basic to an understanding of the structure of fibrous proteins, and there are separate chapters on the silks (of which many kinds are known), collagens, muscle proteins and the keratins. There is a chapter on fibrin, fibrinogen, flagellin, elastin and resilin.

The writing is lucid and critical. The many line diagrams are excellent and there is a good selection of half-tone reproductions, chiefly of diffraction patterns and electron micrographs. The list of references is very comprehensive and it is evident that care has been taken with the indexes. The authors (who have made major contributions to our understanding of fibrous protein structure) are to be congratulated on the publication of such a thorough and useful work.

\section{A. Elliot}

\section{Drifting in the Pacific}

The Settlement of Polynesia: A Computer Simulation. By M. Levison, R. Gerard Ward and J. W. Webb. Pp. $v i+137$. (University of Minnesota Press: Minneapolis, 1973.) $£ 5.50$.

THE question of how the scattered islands of Polynesia were settled during a 2,000-year period ending about a thousand years ago has been a perplexing one for European colonisers whose own methods of navigation only allowed them to arrive there less than 300 years ago. One rather loud voice in the debate in recent times has been that of Andrew Sharp. He simply applied to the problem his hard-headed common sense, Occam's razor, and a due cynicism about far-fetched or fantastical tales of intrepid ancient Polynesian seamen with sophisticated navigational skills. After all, Polynesians were both illiterate and living in the Stone Age. Sharp's thesis is that island discovery took place by unnavigated one-way voyages either of exile, or accidental drift, and that there is no reason to suppose that deliberately navigated journeys of exploration or long voyages with return to the starting place occurred. In the preface to his 1964 book, Sharp states, "It is six years since my previous book ... During those years I have gathered upwards of a hundred published notices... and have been involved in 2,191 oral discussions of the book's themes. I have yet to hear of a fact or read an argument which impugns the basic contentions of the former book". The present book by Levison, Ward and Webb, contains both facts and arguments which do impugn Sharp's contentions.

What Levison, Ward and Webb have done is to take the recorded data of frequencies of different winds and currents throughout the Pacific, and simulate by computer one-way drift voyages from a variety of starting points.

All the assumptions of the simulation seem remarkably sensible. On each day a particular wind and a current direction are chosen randomly from the available recorded frequencies of winds and currents for the particular month in the particular $5^{\circ} \times 5^{\circ}$ (approximately 300 nautical mile) square, and the vessel is moved an appropriate distance and directicn. A craft makes a landfall if its passes within 10 miles of a low island or 20 miles of higher ones. There is a sigmoid curve of increasing tendency of a voyage to end due to factors like death of the crew $(50 \%$ of voyages terminate in this way by 10 weeks). But there is also a 0.5 probability of foundering if a gale of force 9 or above occurs.

The authors have simulated more than 100,000 drift voyages, and 8,000 deliberately guided ones. The drift voyages included a main series of 46,000 from 61 starting points starting every day of the year, 11,000 under shifts of climatic conditions of the kind that might have occurred in the last 2,000 years or so, 32,000 starting from specially advantageous points at specific months of the year, and 10,000 in reverse from destinations towards possible starting points.
Their conclusion was that drifting produced a zero probability of reaching either Hawaii or Easter Island from any inhabited part of Polynesia, and less than $0.1 \%$ chance of reaching New Zealand. Thus drifting alone does not seem to be able to account for the colonisation. Among other things they also show that Kon Tiki would never have reached Easter Island, or anywhere else in Polynesia unless it had been very deliberately steered westward (which it was). Indeed, in simulated voyages with an attempt to hold a particular course, and with a limitation of only being able to lay as close as $90^{\circ}$ to the wind, the chances of reaching the outlying parts of Polynesia become quite reasonable.

Levison et al. are judicious on the subject of relevant archaeological data and the various theories that have been put forward. They also are scrupulous about the technical part of their simulation. Both a complete listing of their ALGOL program and a large selection of their results in the form of maps of scattered destinations of voyages from particular starting places appear in appendices which occupy about half the book. But the non-technical should not be deterred. The text though detailed is well written, and the whole is a substantial contribution. Put together with the recent publications by Gladwin and Lewis of sophisticated navigational techniques still practiced in the Caroline Islands, this work finally disposes of the idea that Polynesians were savages who just happened to have been blown to accidental discovery of the vast reaches of the Pacific which they came to inhabit.

Keith OAtLeY

\section{Relativity with reprints}

General Theory of Relativity. By C. W. Kilmister. Pp.ix +365 . (Commonwealth and International Library: Selected Readings in Physics.) (Pergamon: Oxford and New York, November 1973.) $£ 3.50$ boards; $£ 2$ paper.

ACCORDING to the publisher's note on the back cover, this book meets "the increasing need for an undergraduate text on the general theory of relativity". It will be an unusual undergraduate who absorbs more than a portion of it but there is a need for a textbook for all students with ambitions to research into relativity, cosmology and astrophysics (and pure differential geometry). This should ideally not only present the facts about relativity they need, but also assist the transition from didacticaly helpful lectures to the scientific literature.

This book is important because it has both these aims. Before venturing 